European Journal of Business and Innovation Research

Vol.8, No.2.pp. 48-54, April 2020

Published by ECRTD-UK

Print ISSN: 2053-4019(Print), Online ISSN: 2053-4027(Online)

\title{
FACTORS AFFECTING THE DEVELOPMENT OF BANH PHONG CRAFT VILLAGE: A CASE OF CAI BE DISTRICT IN TIEN GIANG PROVINCE, VIETNAM
}

\author{
Mai Thanh Loan \\ Van Lang University (VLU) \\ Le Hoang Phuong \\ Tien Giang Statistical Office
}

\begin{abstract}
This study aims to estimate the factors affecting the development of Banhphong Craft Village in Cai Be district, Tien Giang province, Vietnam. The sample data of 185 survey questionnaire responses collected by representatives of producers, stratified samples by labor size. The regression analysis results have tested four factors at the 0.05 significance level. They are the financial capacity of the producing household; Infrastructure; Production conditions of the producing household, and the understanding ability of the household head.
\end{abstract}

KEYWORDS: Development, Banh Phong craft village.

\section{INTRODUCTION}

Vietnam's agricultural history is related to countryside and craft villages. Craft villages are not only the connection between industry and agriculture, rural and urban areas, tradition, and present but also an essential step in the process of industrialization in rural Vietnam. The making of Banh Phong in Cai Be district, Tien Giang province, Vietnam, has been found since 1940. In the beginning, people made cakes to use for Tet holidays and gradually produced in large quantities and came onto the market. By 2018, located in Cai Be district, there had been more than 327 business households producing Banh Phong and 8 agents. However, the profitability of cake producers is low and faces difficulties in capital and technology, as well as unplanned production development. The things mentioned above, the researcher chose the topic "Factors affecting the development of Banhphong Craft Village in Cai Be district, Tien Giang province, Vietnam" as a paper. This paper helps producers, associations, and local authorities apply research results to develop craft villages.

\section{LITERATURE REVIEW}

The theoretical basis for the research model is development theory, craft village theory. The following scholars presented the views on development according to Harrison, D. (1988); Ingham, B. (1993); Todaro, M. (1994); Hettne, B. (1995); Redclift, M. (2000). Craft village is a community of people living in the same rural area. It Includes a part of the population that produces one or several types of goods and services, including at least one specific type of goods or services, which attracts a large number of laborers or households in the village to participate. The following scholars presented the views on development craft village: Cohen J. (1998); Scrase T. (2003); (Hartley (2005); (Eversole, 2006); Hesmondhalgh (2007); Stevenson and Scobie (2007); Follett 
(2013).The experimental basis for the proposed research model is the previous relevant studies, including 01 international research papers and 04 domestic research papers. The practical basis for the research paper and also the basis for applying research results is Banh Phong craft village in Cai Be district.

Table 1: Summary of several types of research related to craft village development

\begin{tabular}{|c|c|c|c|}
\hline No & Researcher & Number of studies & Factors affecting the development of craft village \\
\hline 1 & $\begin{array}{l}\text { Naoto Suzuki } \\
\text { (2006) }\end{array}$ & $\begin{array}{l}\text { Development strategy } \\
\text { formulation for artisan craft } \\
\text { promotion }\end{array}$ & $\begin{array}{l}\text { (1) Craft village development strategy } \\
\text { (2) Support services } \\
\text { (3) Handcrafted items } \\
\text { (4) Human resources }\end{array}$ \\
\hline 2 & $\begin{array}{l}\text { Kieu Mai } \\
\text { Huong (2010) }\end{array}$ & $\begin{array}{l}\text { Developing craft villages in } \\
\text { Thach That district, Hanoi } \\
\text { city }\end{array}$ & $\begin{array}{l}\text { (1) Infrastructure } \\
\text { (2) Investment and credit policies } \\
\text { (3) Human resources } \\
\text { (4) Variation of market demand } \\
\text { (5) Technology and technology level } \\
\text { (6) Traditional elements } \\
\text { (7) Production materials of craft villages }\end{array}$ \\
\hline 3 & $\begin{array}{l}\mathrm{Vu} \quad \mathrm{Ngoc} \\
\text { Hoang }(2016)\end{array}$ & $\begin{array}{l}\text { Traditional craft villages in } \\
\text { Nam Dinh province in } \\
\text { international integration }\end{array}$ & $\begin{array}{l}\text { (1) Accessibility to market information } \\
\text { (2) Production technology } \\
\text { (3) The competitiveness of goods } \\
\text { (4) Quality of labor resources } \\
\text { (5) Environmental pollution } \\
\text { (6) Foreign markets } \\
\text { (7) Electronic commerce } \\
\text { (8) Application of science and technology }\end{array}$ \\
\hline 4 & $\begin{array}{l}\text { Đang Kim Chi } \\
\& \operatorname{ctg}(2005)\end{array}$ & $\begin{array}{l}\text { Scientific and practical basis } \\
\text { for formulating policies and } \\
\text { measures to solve } \\
\text { environmental problems in } \\
\text { Vietnamese craft villages }\end{array}$ & $\begin{array}{l}\text { 1) Internal factors } \\
\text { (2) State policies } \\
\text { (3) International integration } \\
\text { (4) Social factors } \\
\text { (5) Environmental factors }\end{array}$ \\
\hline 5 & $\begin{array}{l}\text { Mai Van Nam } \\
\text { (2013) }\end{array}$ & $\begin{array}{l}\text { Factors affecting the } \\
\text { development of craft villages } \\
\text { and tourism in the Mekong } \\
\text { Delta }\end{array}$ & $\begin{array}{l}\text { 1) Financial capacity of the producing households } \\
\text { (2) Infrastructure } \\
\text { (3) Production conditions of the producing households } \\
\text { (4) The understanding ability of the household head }\end{array}$ \\
\hline
\end{tabular}

(Source: The researchers' collecting and proposed)

Table 1 showed that there were five studies related to the development of craft villages. Five studies include Naoto Suzuki (2006), Kieu Mai Huong (2010), Vu Ngoc Hoang (2016), Dang Kim Chi \& ctg (2005), and Mai Van Nam (2013). Based on the thing as mentioned above, the researchers have the model figure 1 bellowed

(Source: The researchers' collecting and proposed)

Figure 2: Research model for factors affecting the development of Banhphong Craft Village in Cai Be district, Tien Giang province, Vietnam

Figure 1 showed that four factors were affecting the development of Banh Phong Craft Village in Cai Be district, Tien Giang province. All of the factors are a positive relationship with the 
development of craft Village. The basis for designing questionnaires is the content of the factorin the model described in table 2 below:

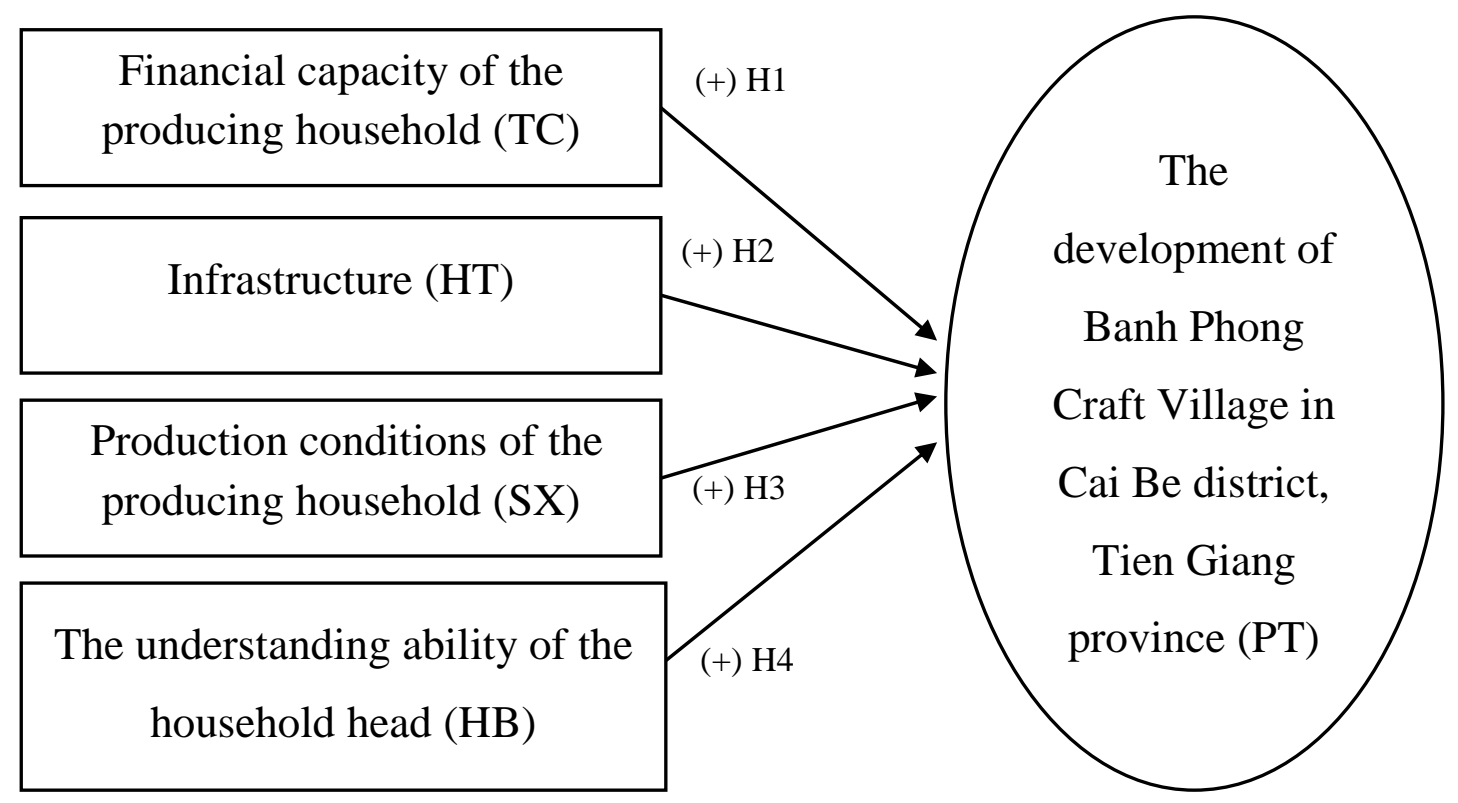

Table 2: Describe variables in the model

\begin{tabular}{|c|c|c|c|c|}
\hline No & Code & Factor(variable) & Describe variables & Sources \\
\hline 1 & PT & $\begin{array}{l}\text { Development of Craft } \\
\text { Village }\end{array}$ & $\begin{array}{l}\text { is a local economic development program to } \\
\text { improve product quality, control input sources, } \\
\text { increase production quantities, and improve supply } \\
\text { chains. }\end{array}$ & $\begin{array}{l}\text { Eversole } \\
\text { (2006) }\end{array}$ \\
\hline 2 & $\mathrm{TC}$ & $\begin{array}{l}\text { The financial capacity } \\
\text { of the producing } \\
\text { household }\end{array}$ & $\begin{array}{l}\text { is the own capital and the borrowed capital of craft } \\
\text { village households to invest in materials, raw } \\
\text { materials, machinery and equipment, labor. }\end{array}$ & $\begin{array}{l}\text { cited by Vu } \\
\text { Ngoc Hoang } \\
(2016)\end{array}$ \\
\hline 3 & HT & Infrastructure & is roads, electricity, and water supply systems. & $\begin{array}{l}\text { cited by Vu } \\
\text { Ngoc Hoang } \\
(2016)\end{array}$ \\
\hline 4 & SX & $\begin{array}{ll}\text { Production } & \text { conditions } \\
\text { of the } & \text { producing } \\
\text { household } & \end{array}$ & $\begin{array}{l}\text { represent the number of human resources and input } \\
\text { materials for the production process together with } \\
\text { local policies that contribute to solving production } \\
\text { difficulties for production households. }\end{array}$ & $\begin{array}{l}\text { cited by Mai } \\
\text { Van Nam } \\
(2013)\end{array}$ \\
\hline 5 & HB & $\begin{array}{l}\text { The understanding } \\
\text { ability of the household } \\
\text { head }\end{array}$ & $\begin{array}{l}\text { is the educational level, the ability to identify } \\
\text { opportunities for production activities from market } \\
\text { information about raw materials, finished products, } \\
\text { etc. }\end{array}$ & $\begin{array}{lr}\text { cited by Mai } \\
\text { Van Nam } \\
\text { (2013) }\end{array}$ \\
\hline
\end{tabular}

(Source: The researchers' collecting and proposed) 
Print ISSN: 2053-4019(Print), Online ISSN: 2053-4027(Online)

\section{METHODS OF RESEARCH}

This research is done through two steps: Qualitative research and Quantitative research. Qualitative research: It is a kind of research used to adjust, modify, and unify observing variables to measure the research concept. This research conducted by a discussion with individuals' representatives of production households, trade associations, and tourism industry management to learn about business characteristics of craft village. The purpose of qualitative research is to inspect the scale and to eliminate unsuitable variables as well as supplementing new significant variables for the research by specific characteristics of business in the area of research. Quantitative research: This study is a quantitative paper that is combined with qualitative research in the proposed research model, suggesting the implication of management from model results. The sample data of 185 survey questionnaire responses. Questionnaires include 23 observed variables. Respondents are representatives of the producing and trading households in the craft village of Banh Phong in Cai Be district, Tien Giang province, Vietnam. The scales that express the concepts in the model are multivariate. The observed variables measured on a 5-level Likert scale that varied from $1=$ strongly disagree to $5=$ strongly agree. Methods of stratified sampling by the establishment's labor size. The survey method is a face-to-face interview. The total number of votes issued was 195, in which 189 votes recollected, and 185 of them were valid.

Table 3. Structure of the population and sample

\begin{tabular}{|c|c|c|c|c|}
\hline \multicolumn{2}{|c|}{$\begin{array}{l}\text { Information of the household } \\
\text { manufacturing }\end{array}$} & $\begin{array}{l}\text { Number } \\
\text { production } \\
\text { households }\end{array}$ & $\begin{array}{l}\text { Overall rate } \\
(\%)\end{array}$ & $\begin{array}{l}\text { Survey sample } \\
\text { rate } \\
(\%)\end{array}$ \\
\hline \multicolumn{5}{|r|}{100} \\
\hline \multirow{3}{*}{$\begin{array}{l}\text { Size } \\
\text { labor } \\
\text { (people) }\end{array}$} & $<5$ & 206 & 62.99 & 63.78 \\
\hline & $5-10$ & 91 & 27.83 & 27.57 \\
\hline & $>10$ & 30 & 9.18 & 8.65 \\
\hline \multicolumn{5}{|c|}{327} \\
\hline $\begin{array}{l}\text { Investment } \\
\text { business }\end{array}$ & $<100$ & 275 & 84.10 & 85.41 \\
\hline \multirow{2}{*}{$\begin{array}{l}\text { (million } \\
\text { VND) }\end{array}$} & $100-900$ & 45 & 13,76 & 11.89 \\
\hline & $>900$ & 7 & 2.14 & 2.70 \\
\hline
\end{tabular}

(Source: survey data)

On the collected data, data analysis includes: measuring the reliability of scales, exploring factor analysis, estimating regression parameters, and tests. 
European Journal of Business and Innovation Research

Vol.8, No.2.pp. 48-54, April 2020

Published by ECRTD-UK

Print ISSN: 2053-4019(Print), Online ISSN: 2053-4027(Online)

\section{RESEARCH RESULTS}

Table 4: Correlation matrix of factors affecting craft village development

\begin{tabular}{|c|c|c|c|c|c|c|}
\hline \multirow{3}{*}{$\overline{\text { PT }}$} & & PT & $\mathrm{HB}$ & HT & TC & SX \\
\hline & Pearson Correlation & 1 & & & & \\
\hline & Sig. (2-tailed) & & & & & \\
\hline \multirow[t]{2}{*}{$\mathrm{HB}$} & Pearson Correlation & ,667*** & 1 & & & \\
\hline & Sig. (2-tailed) &, 000 & & & & \\
\hline \multirow[t]{2}{*}{ HT } & Pearson Correlation &, $626 * *$ & $3866^{* *}$ & 1 & & \\
\hline & Sig. (2-tailed) &, 000 &, 000 & & & \\
\hline \multirow[t]{2}{*}{$\mathrm{TC}$} & Pearson Correlation & ,474** &, $157 *$ &, $281 * *$ & 1 & \\
\hline & Sig. (2-tailed) &, 000 &, 033 &, 000 & & \\
\hline \multirow[t]{2}{*}{ SX } & Pearson Correlation &, $485^{* *}$ &, $222 * *$ &, $173^{*}$ &, $222 * *$ & 1 \\
\hline & Sig. (2-tailed) & .000 & .002 & 018 & .002 & \\
\hline
\end{tabular}

**. Correlation is significant at the 0.01 level (2-tailed).

*. Correlation is significant at the 0.05 level (2-tailed).

(Source: The researchers' processing SPSS 22.0)

Table 4 shows a positive and quite strong correlation between the independent and dependent variables.

Table 5: The summary output of factors affecting craft village development

\begin{tabular}{|l|l|l|l|l|}
\hline Model & $\begin{array}{l}\text { Standardized } \\
\text { Coefficients }\end{array}$ & t & sig & VIF \\
\hline (Constant) & & $-3,705$ & 000 & \\
\hline HB & 436 & 10,724 &, 000 & 1,211 \\
\hline HT &, 340 & 8,224 &, 000 & 1,252 \\
\hline TC &, 249 & 6,358 &, 000 & 1,124 \\
\hline SX &, 274 & 7,072 &, 000 & 1,096 \\
\hline$R^{2}$ Adjusted $=0,749$ & & & &
\end{tabular}

$\mathrm{R}^{2}$ Adjusted $=0,749$

Sig. F change $=0,000$

Durbin-Watson $=1,552$

Sig.F $=0,000$

a. Dependent Variable: PT

b. Predictors: (Constant), SX, HT, TC, HB

(Source: The researchers' processing SPSS 22.0)

Table 5 shows the development of craft villages explained by 4 independent variables of the model significance level of 0.05 . Arrange 4 variables in descending order: The understanding ability of the household head (HB), Infrastructure (HT), Production conditions of the producing household (SX), Financial capacity of the producing household (TC). 
European Journal of Business and Innovation Research

Vol.8, No.2.pp. 48-54, April 2020

Published by ECRTD-UK

Print ISSN: 2053-4019(Print), Online ISSN: 2053-4027(Online)

\section{CONCLUSIONS AND MANAGERIAL IMPLICATIONS}

\section{Conclusions}

Based on the findings of this study, the following conclusions drawn. Chi-Square testing of model suitability meets inspection standards, for conclusions:

1. Adjusted $R$ Square $=74,9 \%$ : reflecting $74.9 \%$ of the change in the development of the Craft Village due to the change of 4 factors

2. Besides, the results of other tests:(1) Multicollinearity testing: VIF are all <10: there are no signs of multicollinearity. (2) Durbin-Watson $=1,552(1<\mathrm{D}<3)$ : The model has no autocorrelation. (3) The model does not violate the uniform variance hypothesis, does not violate the assumption that violates the normal distribution hypothesis of residuals.

3. The link between research results and practice in the craft village: Arrange 4 variables in descending order: The understanding ability of the household head (HB), Infrastructure (HT), Production conditions of the producing household (SX), Financial capacity of the producing household (TC). This factor is consistent with the situation in the craft village: (1) Production household heads are managed by their experience. However, for sustainable development, they lack knowledge of production and business management. (2) Over the past few years, the New Rural Program has upgraded transportation, electricity, and water, and this directly affects the development of the Craft Village. However, to develop in the age of technology, craft villages need to pay attention to technology infrastructure. (3) Human resources of production households are mainly direct workers with genetic experience, and they lack managers who can develop production and supply chain. Stable material source, but rudimentary machinery. All do not gear towards larger-scale production. (4) Production households are limited in the capital, and the government has created favorable conditions for them to access low-cost capital sources, which has partly helped establishments have flexibility in financial solutions.

4. $\quad$ Compared to previous studies: model results are similar to previous studies.

\section{Managerial implications}

Based on the findings and conclusions about the model, the following recommendations proposed: Firstly, about improving The understanding ability of the household head: Local authorities and professional associations should focus on training them with management knowledge, especially in the short-term, knowledge about suppliers and supply chains. Secondly, to improve production conditions of production households: local governments and professional associations need to support training, consulting, research, and application of advanced science and technology, technology transfer to for production. Thirdly, about craft village organization: The craft village needs to build a centralized model to develop the supply chain from raw materials to consumer markets, such as trade centers, wholesale markets, tourist destinations and restaurants, hotels. In parallel, craft villages need to build a brand and apply digital marketing. Fourthly, on the financial capacity of production households: it is necessary to have the highest initiative from the owner to access the low-cost capital. Craft villages also need to set up representative boards and cooperatives for greater funding and investment. 
European Journal of Business and Innovation Research

Vol.8, No.2.pp. 48-54, April 2020

Published by ECRTD-UK

Print ISSN: 2053-4019(Print), Online ISSN: 2053-4027(Online)

Proposing the next research direction:(1) Adding independent variables to the research model in the direction of testing business environment factors. At the same time, expand the scope of research to other craft villages so that the model tested more widely. (2) In the same study area (Banh Phong trade village in Cai Be district, Tien Giang province, Vietnam): Other research models should be tested for a complete picture.

\section{References}

Cohen J. (1998), Craft Production and the Challenge of the Global Market: an Artisans' Cooperative in Oaxaca, Mexico, Human Organization 57(1): 74-82.

Dang Kim Chi (2005), Scientific and practical basis for formulating policies and measures to solve environmental problems in Vietnamese craft villages, Project KC.08.09, Institute of Environmental Science and Technology, Hanoi University of Science and Technology.

Eversole (2006), Crafting development in Bolivia. Journal of International Development, J. Int. Dev. 18, 945-955

Evan, J. D., (1996), Straightforward statistics for the behavioral sciences. Belmont, CA: Wadsworth

Harrison, D., (1988), The Sociology of Modernization and Development. London: Routledge.

Hettne, B., (1995), Development Theory, and the Three Worlds. New York: Longman.

$\mathrm{Vu}$ Ngoc Hoang (2016), Traditional craft villages in Nam Dinh province in international integration, Doctoral Thesis, Ho Chi Minh National Political Academy.

Kieu Mai Huong (2011), Developing craft villages in Thach That district, Hanoi city, Master's thesis, Hanoi National University.

Ingham, B., (1993), The meaning of development: Interactions between new and old ideas. World Development 21 (11), 1803-21.

Tran Thi Thuy Linh (2012), Developing the craft village system in Ben Tre Province: Current situation and solutions, Master's thesis, Ho Chi Minh City University of Education.

Mai Văn Nam (2013), Factors affecting the development of craft villages and tourism in the Mekong Delta, Journal of Economic Research, No. 422, July 2013.

Redclift, M., (2000), Sustainability, Life Chances, and Livelihoods. London: Routledge.

Scrase T., (2003), Precarious Production: Globalization and Artisan Labor in the Third World. Third World Quarterly 24 (3): 449-461.

Todaro, M., (1994), Economic Development (5th end). New York: Longman.

The Circular No. 116/2006/TT-BNN of the Ministry of Agriculture and Rural Development of Vietnam. 